\title{
INSTRUCTIONS FOR CONTRIBUTORS
}

\section{SUBMISSION OF MANUSCRIPTS}

Manuscripts should be submitted online via our manuscript submission and tracking site, http://www.editorialmanager.com/psm/. Full instructions for electronic submission are available directly from this site. To facilitate rapid reviewing, communications for peer review will be electronic and authors will need to supply a current e-mail address when registering to use the system.

Papers for publication from Europe (except those on genetic topics, irrespective of country), and all papers on imaging topics, should be submitted to the UK Office.

Papers from the Americas, Asia, Africa, Australasia and the Middle East (except those dealing with imaging topics), and all papers dealing with genetic topics, irrespective of country, should be sent to US Office.

Generally papers should not have text more than 4500 words in length (excluding these sections) and should not have more than a combined total of 5 tables and/or figures. Papers shorter than these limits are encouraged. For papers of unusual importance the editors may waive these requirements. A structured abstract of no more than 250 words should be given at the beginning of the article using the headings: Background; Methods; Results; Conclusions. The name of an author to whom correspondence should be sent must be indicated and a full postal address given in the footnote. Any acknowledgements should be placed at the end of the text (before the References section).

Declaration of Interest: A statement must be provided in the acknowledgements listing all financial support received for the work and, for all authors, any financial involvement (including employment, fees, share ownership) or affiliation with any organization whose financial interests may be affected by material in the manuscript, or which might potentially bias it. This applies to all papers including editorials and letters to the editor.

Contributors should also note the following:

1. S.I. units should be used throughout in text, figures and tables.

2. Authors should spell out in full any abbreviations used in their manuscripts.

3. Foreign quotations and phrases should be followed by a translation.

4. If necessary, guidelines for statistical presentation may be found in: Altman DG, Gore SM, Gardner MJ \& Pocock SJ (1983). Statistical guidelines for contributors to medical journals. British Medical Journal 286, 1489-1493.

REFERENCES (1) The Harvard (author-date) system should be used in the text and a complete list of References cited given at the end of the article. In a text citation of a work by more than two authors cite the first author's name followed by et al. (but the names of all of the authors should be given in the References section). Where several references are cited together they should be listed in rising date order. (2) The References section should be supplied in alphabetical order (authors' names in bold, journal titles in full), following the text. Some examples follow:

Miller PM, Byrne M, Hodges A, Lawrie SM, Johnstone EC (2002). Childhood behaviour, psychotic symptoms and psychosis onset in young people at high risk of schizophrenia: early findings from the Edinburgh high risk study. Psychological Medicine 32, $173-179$.

Cleckley HJ (1941). The Mask of Sanity, 2nd edn. Mosby: St. Louis, MO.

Brewer WJ, Wood SJ, DeLuca C, Pantelis C (2006). Models of olfaction for exploring neurodevelopment. In Olfaction and the Brain (ed. W. J. Brewer, D. Castle and C. Pantelis), pp. 97-121. Cambridge University Press: Cambridge.

(3) Online citations

doi (when published online prior to printed issue)

Lauritsen MB, Pedersen CB, Mortensen CB (2004). The incidence and prevalence of pervasive developmental disorders: a Danish population-based study. Psychological Medicine. Published online: 21 October 2004. doi:10.1017/ S0033291704002387.

URL

World Bank (2003). Quantitative techniques for health equity analysis - Technical Notes (http://siteresources.worldbank. org/INTPAH/ Resources/Publications/Quantitative-Techniques/health.eq tn07.pdf). Accessed 15 February 2006.

[Authors are requested to print-out and keep a copy of any online-only material, in case the URL changes or is no longer maintained.]

FIGURES AND TABLES Only essential figures and tables should be included. Further tables, figures, photographs and appendices, may be included with the online version on the journal website. To ensure that your figures are reproduced to the highest possible standards, Cambridge Journals recommends the following formats and resolutions for supplying electronic figures. Please ensure that your figures are saved at final publication size and are in our recommended file formats. Following these guidelines will result in high quality images being reproduced in both the print and the online versions of the journal. Line artwork: Format: tif or eps, Colour mode: black and white (also known as 1-bit), Resolution: 1200 dpi; Combination artwork (line/tone): Format: tif or eps, Colour mode: grayscale (also known as 8-bit), Resolution: 800 dpi; Black and white halftone artwork: Format: tif, Colour mode: grayscale (also known as 8-bit), Resolution: 300 dpi; Colour halftone artwork: Format: tif, Colour mode: CMYK colour, Resolution: $300 \mathrm{dpi}$. All photographs, graphs, and diagrams should be referred to as figures and should be numbered consecutively in Arabic numerals. Captions for figures should be typed double-spaced on separate sheets. Tables Tables should be numbered consecutively in the text in Arabic numerals and each typed on a separate sheet after the References section. Titles should be typed above the table.

PROOFS AND OFFPRINTS Page proofs will be sent to the author designated to receive correspondence. corrections other than to printer's errors may be charged to the author. The corresponding author of each paper will receive a PDF file of their article and hard copy offprints may be purchased if they are ordered on the form supplied when the proof is returned. 


\section{PSYCHOLOGICAL MEDICINE}

\section{CONTENTS}

\section{REVIEW ARTICLES}

Psychological interventions for ICD-11 complex PTSD symptoms: systematic review and meta-analysis Karatzias T, Murphy P, Cloitre M, Bisson J, Roberts N, Shevlin M, Hyland P, Maercker A, Ben-Ezra M, Coventry P, Mason-Roberts S, Bradley A \& Hutton P

Is there a female cycle of violence after exposure to childhood maltreatment? A meta-analysis

Augsburger M, Basler K \& Maercker A

Technology-based parenting interventions for children's physical and psychological health: a systematic review and meta-analysis

Flujas-Contreras JM, García-Palacios A \& Gómez I

\section{ORIGINAL ARTICLES}

Reasoning bias, working memory performance and a transdiagnostic phenotype of affective disturbances and psychotic experiences in the general population Reininghaus U, Rauschenberg C, ten Have M, de Graaf R, van Dorsselaer S, Simons CJP, Gunther N, Pries L-K, Guloksuz S, Radhakrishnan R, Bak M \& van Os J

Heart rate variability during a cognitive reappraisal task in female patients with borderline personality disorder: the role of comorbid posttraumatic stress disorder and dissociation Krause-Utz A, Walther J-C, Lis S, Schmahl C \& Bohus M

Prefrontal glutamate levels predict altered amygdalaprefrontal connectivity in traumatized youths

Ousdal OT, Milde AM, Craven AR, Ersland L, Endestad T,

Melinder A, Huys QJ \& Hugdahl K

Trauma-associated anterior cingulate connectivity during reward learning predicts affective and anxiety states in young adults

Eckstrand KL, Hanford LC, Bertocci MA, Chase HW,

Greenberg T, Lockovich J, Stiffler R, Aslam HA, Graur S,

Bebko G, Forbes EE \& Phillips ML

Attention-deficit/hyperactivity disorder and clinically diagnosed obesity in adolescence and young adulthood: a register-based study in Sweden

Chen Q, Hartman CA, Kuja-Halkola R, Faraone SV,

Almqvist $\mathrm{C}$ \& Larsson $\mathrm{H}$

Mamma Mia - A randomized controlled trial of an internetbased intervention for perinatal depression

Haga SM, Drozd F, Lisøy C, Wentzel-Larsen T \& Slinning K
Peroxisome proliferator-activated receptor gamma coactivator-1 alpha in depression and the response to electroconvulsive therapy

Ryan KM, Patterson I \& McLoughlin DM

Suicidal ideation and other persisting symptoms after CBT or antidepressant medication treatment for major depressive disorder

Dunlop BW, Polychroniou PE, Rakofsky JJ, Nemeroff CB, Craighead WE \& Mayberg HS

Interaction between environmental and familial affective risk impacts psychosis admixture in states of affective dysregulation

Radhakrishnan R, Guloksuz S, ten Have M, de Graaf R, van Dorsselaer S, Gunther N, Rauschenberg C, Reininghaus U, Pries L-K, Bak M \& van Os J

Aberrant myelination of the cingulum and Schneiderian delusions in schizophrenia: a 7T magnetization transfer study Palaniyappan L, Al-Radaideh A, Mougin O, Das T, Gowland P \& Liddle PF

Deficient auditory predictive coding during vocalization in the psychosis risk syndrome and in early illness schizophrenia: the final expanded sample

Mathalon DH, Roach BJ, Ferri JM, Loewy RL, Stuart BK,

Perez VB, Trujillo TH \& Ford JM

Linking genes, circuits, and behavior: network connectivity as a novel endophenotype of externalizing

Sadeh N, Spielberg JM, Logue MW, Hayes JP, Wolf EJ, McGlinchey RE, Milberg WP, Schichman SA, Stone A \& Miller MW

Trajectories of psychiatric diagnoses and medication usage in youth with 22q11.2 deletion syndrome: a 9-year longitudinal study

Kates WR, Mariano MA, Antshel KM, Chandra S, Gamble H, Giordano M, MacMaster E, Mattar M, St Fleur D, Faraone SV \& Fremont WP

Core psychopathology of treatment-seeking patients with binge-eating disorder: a network analysis investigation Wang SB, Jones PJ, Dreier M, Elliott H \& Grilo CM

Comparison of cognitive functions between first-episode schizophrenia patients, their unaffected siblings and individuals at clinical high-risk for psychosis
Chu AOK, Chang WC, Chan SKW, Lee EHM, Hui CLM \& Chen $\mathrm{EYH}$ 